\title{
Government Budget Deficit in the Regency/City Jambi Province through a Micro Approach
}

\author{
Junaidi $^{1}$, Syamsurijal Tan ${ }^{2}$, Junaidi ${ }^{3 *}$, Arman Delis ${ }^{4}$ \\ ${ }^{1}$ Doctoral Program in Economics, Universitas Jambi, Indonesia \\ ${ }^{2-4}$ Department of Economics, Faculty of Economics and Business, Universitas Jambi, Indonesia
}

DOI: $10.36348 /$ sjef.2020.v04i04.001

| Received: 26.03.2020 | Accepted: 08.04.2020 | Published: 11.04.2020

*Corresponding author: Junaidi

\section{Abstract}

The budget deficit illustrates the sub-optimal revenue of a region. When viewed from a micro approach related to the lack of services to the community it also becomes very important in development planning and strategies set by the government in achieving development goals. The objectives of this study are 1). How is the development of the district / city-regional government budget deficit in Jambi Province in the 2000-2016 fiscal year, 2). How is the degree of fiscal decentralization and the financial dependence of districts/cities in Jambi Province, 3). What factors affect the budget deficit of Regency /City Governments in Jambi Province from the micro side. The source of data used in this study uses secondary data and primary data. The number of respondents using the calculation analysis obtained 140 respondents from 5 districts/cities in Jambi Province. Based on the analysis results obtained that: 1) The highest budget deficit in the West Tanjung Jabung Regency Government during the analysis period when compared with other regencies/cities in Jambi Province, namely in the amount of Rp. 338,586 million occurred in 2013, while the lowest bud get deficit occurred in 2012 of Rp. Rp. 60,000 Million, 2) the degree of fiscal decentralization in Jambi Province in 2002-2006, the percentage of PAD to TPD experienced a significant increase. But in 2007 the percentage of PAD to TPD again declined by 37.83 percent. While the regional independence ratio for 1998-2017 was 63.57 percent and in the category of medium capability, 3). Based on the results of the regression analysis it was found that political and corruption variables had a negative and significant effect on the budget deficit, while for the human resource variable a positive and significant effect against budget deficits.

Keywords: Government Budget, Fiscal Policy, Fiscal Budget, Deficit Budget.

Copyright @ 2020: This is an open-access article distributed under the terms of the Creative Commons Attribution license which permits unrestricted use, distribution, and reproduction in any medium for non-commercial use (NonCommercial, or CC-BY-NC) provided the original author and source are credited.

\section{INTRODUCTION}

The granting of regional autonomy affects the economic growth of a region because it gives freedom to local governments to make their own financial plans and make policies that can affect the progress of their regions. Based on MPR Decree No.XV/MPR/1998, the government issued a policy on regional autonomy on January 1, 2001, The Government of the Republic of Indonesia formally declared the start of the implementation of regional autonomy. According to Bratakusumah, Supriyadi, and Solihin [1], regional autonomy based on Law No.22 of 1999 has a more decentralized nuance, in which the provincial region as an autonomous region as well as an administrative region, exercising its authority is the central government delegated to the governor.

Economic activities carried out by an area or region are always faced with efforts to improve the welfare of its population. In this case, economic growth is a condition for achieving a prosperous society. Economic development is not only focused on economic development, but also on improving the welfare, security, and quality of available resources. These resources are not only about processing natural resources, but also about improving the quality of human resources. Specifically for economic growth, a conducive policy is needed to be in accordance with the targets set.

Fiscal policy has various objectives in driving regional economic activities, namely increasing economic growth, price stability, and income distribution. The impact of fiscal policy on economic growth is expected to be always positive, while the impact on inflation is expected to be negative. But in theory, an expansionary fiscal policy carried out by increasing government spending without an increase in tax sources, as the main source of government finance, 
will result in an increase in the budget deficit [2]. So that the challenges of fiscal policy going forward are not only in determining the appropriate financing strategy but also in the problem of controlling the budget deficit [3]. money [3]. The impact of the budget deficit on the method of adding money in the economy will cause problems of increasing levels of prices of goods and services, thus causing an increase in inflation [2]. According to, Joko Waluyo [4] proves that every time there is an increase in the withdrawal of new foreign debt, it increases foreign exchange reserves. The addition of foreign exchange reserves will cause an increase in base money. After base money with a money multiplier, it will have an impact on increasing the price level. Additional capital inflow from foreign debt will increase government spending so that government investment also increases. Nizar Muhammad [5], proves that (i) the budget deficit has a positive effect on the current account deficit. In the period 1990 - 2012 the effect of the budget deficit was relatively small and took place quickly (one quarter), whereas in the period 1990 - 1997 the effect was greater and with a longer duration (two quarters or one semester), and (ii) the results of this study confirm and in line with the twin deficit hypothesis. According to Syarifah Labibah [6], it proves that there is a positive relationship between Budget Deficit and Inflation in Indonesia in the long term but it is not significant. The error correction model (ECM) estimation results found residual value or error correction term found to be significant at the $1 \%$ level. According to Khairunnisa a [7] proves that GDP (gross domestic product) has a negative effect on the budget deficit. Variables (money supply) show a positive and significant effect on the budget deficit. The effect of M1 on the budget deficit is only statistically significant. While the exchange rate variable has a positive effect on the budget deficit. According to Syarifah Labibah [6], it proves that there is a positive relationship between Budget Deficit and Inflation in Indonesia in the long term but it is not significant. The error correction model (ECM) estimation results found residual value or error correction term found to be significant at the $1 \%$ level. According to Khairunnisa a [7] proves that GDP (gross domestic product) has a negative effect on the budget deficit. Variables (money supply) show a positive and significant effect on the budget deficit. The effect of M1 on the budget deficit is only statistically significant. While the exchange rate variable has a positive effect on the budget deficit. According to Nurfadhilah [8], research proves that the budget deficit has a positive and significant effect on interest rates. While government debt shows a negative and significant relationship to interest rates.

Bearing in mind that the level of regional bureaucratic corruption in Indonesia is still high, this is shown in a survey of bureaucratic corruption trends conducted by PERC. In 1999, the tendency for bureaucratic corruption was 8.0 on a scale of $0-10$. Where zero means absolute net and 10 means absolute tends to corruption. And one year later, in 2000, this figure did not improve. Based on the results of these studies, it is better to increase PAD if it is prioritized by reducing leakage of local government revenue that has not existed by increasing taxes because it will cause misery to the people [9]. Good cash planning will ensure the availability of funds to finance government activities. This certainly can prevent the possibility of delays in an activity due to the unavailability of funds [10]. Especially with the existence of regulations as a guide in working, employee competencies are needed to understand and make decisions [11]. According to Utomo [12], local governments must also be more oriented towards improving performance as a result of the implementation of regional autonomy so that regional dependencies on the center are reduced. In line with Thoha's opinion, according to Halim [13], human resource competency (HR) is a factor that causes low budget absorption. One of them is seen in the process of procurement of goods and services, where there are limited human resources when holding auctions. As a result, the auction process was disrupted because they had to follow the time availability of the auction committee.

Table-1: Budget deficit by Regencies/Cities in Jambi Province 2012-2017 (million rupiah)

\begin{tabular}{|c|c|c|c|c|c|c|}
\hline Regencies/Cities & $\mathbf{2 0 1 2}$ & $\mathbf{2 0 1 3}$ & $\mathbf{2 0 1 4}$ & $\mathbf{2 0 1 5}$ & $\mathbf{2 0 1 6}$ & $\mathbf{2 0 1 7}$ \\
\hline Batanghari & 25.237 & 53.273 & 57.027 & 54.046 & 47.965 & 16.463 \\
\hline Bungo & 6.144 & 105.000 & 69.000 & 110.075 & 53.707 & 943.615 \\
\hline Kerinci & 80.000 & 41.740 & 49.445 & 50.546 & 56.384 & 25.501 \\
\hline Merangin & 19.309 & 24.299 & 17.831 & 28.739 & 38.375 & -58.066 \\
\hline Muaro Jambi & 44.333 & 52.855 & 122.829 & 28.645 & 6.051 & 46.747 \\
\hline Sarolangun & 19.608 & 29.750 & -45.230 & 49.324 & 40.765 & 14.849 \\
\hline Tanjab Barat & 139.000 & 338.586 & 321.710 & 299.963 & 0.0000 & 60.000 \\
\hline Tanjab Timur & 110.262 & 118.430 & 113.353 & 73.063 & 39.027 & 49.291 \\
\hline Tebo & 8.156 & 25,000 & 25.000 & 40.000 & 72.817 & 5.718 \\
\hline Kota Jambi & 18.606 & 12.752 & 44.132 & 83.533 & 83.822 & 111.873 \\
\hline Kota Sungai Penuh & 112.463 & 114.157 & 60.515 & 106.278 & 89.411 & 21.000 \\
\hline
\end{tabular}

Source: Office of financial management and regional assets of Jambi Province, 2018 
Based on the table above the development of the budget deficit in the Regency/City Government in Jambi Province from 2012-2017 fluctuates every year. The highest budget deficit in 2017 occurred in the city of Jambi in the amount of Rp. $111,873,167,565$, - and the District with the lowest budget deficit in the same year period occurred in Tanjung Jabung Barat Regency. The regional government of Jambi City has not optimally utilized the potential of its area, as the provincial capital, Jambi City is more focused on building infrastructure for community services, such as road construction and electricity distribution to the region. Based on the background of the problems outlined above, it is very interesting to analyze the "District / City Government Budget Deficit in Jambi Province (Micro Approach Study) so that 1). How is the development of the district/city regional government budget deficit in Jambi Province [14]. What is the degree of fiscal decentralization and fiscal dependency of regencies/cities in Jambi Province, and 3). What factors affect the budget deficit of regency/municipal governments in Jambi Province from the micro side in terms of politics, human resources, and corruption

\section{LITERATUR REVIEW Regional autonomy}

Regional autonomy is an embodiment of the implementation of government affairs based on the principle of decentralization, namely the transfer of government affairs to the regions to take care of their households. According to Yani [15], one of the matters assigned to the regions is regarding matters that provide income to the Regional Government and the potential to be developed in extracting new sources of revenue for the region concerned because this PAD is expected to be able to finance regional routine expenditure.

According to Law Number 32 of 2004 concerning Regional Government Article 1 paragraph 5 "Regional autonomy is the right, authority and obligation of autonomous regions to regulate and manage their own government affairs and the interests of local communities in accordance with statutory regulations according to the Secretary of the Directorate General of Central and Regional Financial Balance. Ministry of Finance Djoko Hidayanto in 2004. The main mission of the implementation of regional autonomy is (a) improving the quality and quantity of public services and public welfare. (b) creating efficiency and effectiveness in the management of regional resources. (c) empower and create space for the community to participate in development. According to Widjaja [16] "The essence of the concept of implementing regional autonomy is the effort to maximize regional implementation starting from 2001".

\section{Budget concept}

The budget is a guideline for action to be carried out by the government including plans, revenue, expenditure, transfers, and financing measured in rupiahs arranged systematically according to certain classifications for one period. According to Mardiasmo, [17] states that the public sector budget is financial planning about the estimated expenditure and revenues expected to occur in the future by looking at data obtained from the past as a reference for determining the budget. According to [18] explains that the types of the budget in public sector accounting: Line item budgeting is the preparation of the budget based on and from where the funds (revenue posts), and for what the funds are used (expenditure items). According to Wahyuningtyas, et al. [19] in its implementation, the APBN has several functions, namely: 1) Functional, 2) Planning Function, 3). Monitoring Function, 4). Allocation Function, and 5). Stabilization function. According to Halim [20], the Regional Revenue and Expenditure Budget (APBD) is a regional budget that has the following elements: (a) The existence of a regional activity plan, (b) There are sources of revenue, (c) There are expenses.

\section{Regional government financial performance}

Performance is defined as the measurable activity of an entity during a certain period as part of the measurement of the success of Riwayadi's work [21]. Performance measurement is a form of accountability, where a higher assessment becomes a guide that must be met, performance measurement data can be a further improvement of the program.

According to Sedarmayanti [22] performance (performance) is defined as the result of a worker, a management process or an organization as a whole, where the results of the work must be measured by comparison with predetermined standards. According to Mardiasmo [23], the public sector performance measurement system is a system that aims to help public managers assess the achievement of a strategy through financial and nonfinancial measures. One of the tools to analyze regional financial performance in managing regional finances is by analyzing financial ratios against the APBD that have been established and implemented [13].

\section{Locally-generated revenue}

According to Mardiasmo [17], regional ownsource revenue is revenue obtained from the regional tax sector, regional levies, results of regionally-owned companies, the results of the management of separated regional assets, and other legitimate regional own-source revenues. According to Lewis in Ahyani [24], the ineffectiveness of various regulations carried out by the government may indicate that there is no positive relationship between these new levies and the seriousness of the regional government in improving the quality of public services. 


\section{Fiscal decentralization policy}

Fiscal policy is always linked to the interests of the government through tax revenue rights, government spending, and government loans aimed at creating jobs, controlling prices, and maintaining economic growth to remain positive. The concept of fiscal policy was first applied on a large scale in America in the 1930s, namely when the depression hit the American economy. At that time the government needed money to finance various types of projects to accommodate a large workforce (due to unemployment) and aimed at rehabilitating a sluggish economy [25]. According to Boediono [26] fiscal policy can be seen from the structure of APBN posts. Where the State Budget has two sides, namely the side that records expenses and the side that records revenues. According to Boediono [27] there are four main sources to obtain these funds, namely a) Various taxes, b) Loans from the central bank, c) Loans from the domestic community, d) Loans from abroad. In other words, a fiscal policy is a combined flow of APBN items with various mechanisms, which can affect the economy as a whole.

\section{Budget deficit}

According to Barro [28] there are several reasons for the budget deficit, among others 1) accelerating economic growth that is not matched by an adequate supply of funds, 2) Increasing public income so that the government requires a large enough cost.3) Weakening the exchange rate. 4). Economic Crisis, 5). Realization that deviates from the plan, 6). Expenditures due to inflation

\section{Capital expenditure}

Capital Expenditures is one type of Direct Expenditures in the APBN / APBD. According to Erlina, Rasdianto [29] Capital Expenditures are budget expenditures for tangible fixed assets that benefit more than one accounting period. The purchasing process is generally done through a fairly complicated auction or tender process. According to Halim [13], capital expenditure is expenditure whose benefits exceed one fiscal year and will increase regional assets or wealth and will have consequences to add to routine expenditures such as maintenance costs. Another difference is that operational budgets are usually designed for one year of expenditure, while most capital budgets are for several periods or fiscal years [30].

According to Kuznets [31], economic growth (economic growth) is a long-term increase in the capacity of the country concerned to provide various economic goods to its population. According to Todaro [32], there are three main factors in economic growth, namely: (a) Capital accumulation, (b) Population growth, (c) Number of workers, (d) Technological progress. According to Tan [33], stating that to get high economic growth, it must be sourced from high GDP as well. According to Tan [33], economic growth is a process of increasing the income of a country or region in the long run, in its calculation, it is always calculated in one year. While per capita output growth is used as an indicator of changes in economic welfare [34].

Investment can be interpreted as expenditure or expenditure of investors or companies, to buy capital goods and production equipment to increase ability, produce goods and services available in the economy [35]. Investment according to Dornbusch [35] is expenditures to buy capital goods and production equipment to replace and especially adding capital goods in the economy that will be used to produce goods and services in the future.

\section{METHODS \\ Methods of data analysis}

According to Sugiyono [36], the population is a generalization area consisting of objects, subjects that have certain qualities and characteristics that are determined by researchers to be studied and then drawn conclusions. From the total population, there will be taken by the sample Slovin formula [37] obtained the number of respondents by 140 respondents from 11 districts/cities in Jambi Province which is divided into 2 regions, namely the western region of Jambi 5 districts/cities and the eastern part of Jambi 5 Regency/City and primary data derived from respondents' answers to some questions raised by researchers through interviews and questionnaires. A questionnaire is a number of written questions that are used to obtain information from the respondent in the sense of a report about his personality, or things he knows [38].

In addition, this study also uses secondary data with 2012-2017 time series data types and the data sources needed in this study come from the Central Statistics Agency (BPS) of Jambi Province and the Regional Finance Agency of Jambi Province, as well as references to library studies through journals, articles, papers, previous research, other materials obtained from the UNJA library, the internet, and other sources related to this study.

\section{RESEARCH STRATEGY}

The analysis technique used in this research is descriptive analysis and regression analysis. This analysis was carried out to answer the first research objective, namely to analyze the development of the Jambi Provincial Government budget deficit using several analytical instruments such as tables and graphs that can reflect the analysis of research analysis on a regular and mutually supportive basis. Quantitative Analysis. The formula for developing a budget deficit is as follows: 
$G_{D A}=\frac{D A_{t}-D A_{t-1}}{D A_{t-1}} x 100 \%$

Analysis of Regional Revenue Financial Ratios is used to answer the second research objective, namely to analyze the degree of fiscal decentralization, and regional financial independence Based on this, then in this study, a ratio was formulated that was used to

Degree of Decentralization $=\frac{\text { Locally-generated revenue }}{\text { Total Regional Revenue }} \times 100 \%$

measure financial performance in Jambi Province, the higher the PAD, the more high ability of local governments in the implementation of decentralization. The following formula for calculating the degree of decentralization:

The degree of decentralization can be seen from the comparison of PAD and TPD. The criteria for

Table-2: Criteria for assessing the level of fiscal decentralization

\begin{tabular}{|c|c|}
\hline Percentage of PAD to TPD & Level of Fiscal Decentralization \\
\hline $0,00-10,00$ & Very low \\
\hline $10,01-20,00$ & Low \\
\hline $20,01-30,00$ & Medium \\
\hline $30,01-40,00$ & Enough \\
\hline $40,01-50,00$ & Well \\
\hline$>50,00$ & Very good \\
\hline
\end{tabular}

Source: Ministry of home affairs R\&D Team -UGM Faculty of Social and Political Sciences, 1991

The higher this ratio, the greater the level of independence of the regional government towards the central or provincial government. The following assessing the level of fiscal decentralization can be categorized as the following table:

Independence Ratio $=\frac{\text { Locally-generated revenue }}{\text { Central Transfers }+ \text { Province }+ \text { Loans }} X 100 \% \ldots \ldots \ldots . . . .$.

One of the successes of regional financial capacity in implementing regional autonomy is seen from the financial independence of the region. An area that is already independent in the financial aspect is expected to be able to carry out development and formula for calculating the Regional Financial Independence Ratio:

Table-3: The pattern of relationships and the level of regional capability

\begin{tabular}{|c|c|}
\hline Percentage & Regional Financial Independence \\
\hline $0,00-10,00$ & Very low \\
\hline $10,01-20,00$ & Low \\
\hline $20,01-30,00$ & Medium \\
\hline $30,01-40,00$ & Enough \\
\hline $40,01-50,00$ & High \\
\hline$>50,00$ & Very High \\
\hline
\end{tabular}

Source: Ministry of Home Affairs Research and Development Team - UGM Faculty of Social and Political Sciences, 1991 (processed)

Data Panel has several data processing techniques, namely Pooled Least Square, Fixed Effect, and Random Effect [39]. This analysis is carried out to answer the fourth research objective, which is to analyze what factors affect the budget deficit of the Regency / City Government in Jambi Province from the micro side by using the econometric model to reflect services to the community without expecting funds to be transferred from the central government. As a guideline in seeing the pattern of relations with the ability of the region in terms of finance can be seen as shown in the following table 3 :

$Y_{t}=\alpha_{0}+\alpha_{1} X_{1 t}+\alpha_{2} X_{2 t}+\alpha_{3} X_{3 t}+e_{t}$ 
Micro equation function:

$\mathrm{KA}: \mathrm{f}\{\mathrm{PO}, \mathrm{KP}, \mathrm{SDM}\}$

So the time series equation can be written as follows:

$\mathrm{KA}_{\mathrm{t}}=\alpha_{0}+\beta_{1} \mathrm{PO}_{\mathrm{t}}+\beta_{2} \mathrm{KP}_{\mathrm{t}}+\beta_{3} \mathrm{SDM}_{\mathrm{t}}+\mathrm{e}_{\mathrm{t}}$

Where:

$\begin{array}{ll}\alpha & =\text { Intercept coefficient } \\ \beta & =\text { Slope or slope coefficient } \\ \mathrm{PO} & =\text { Political } \\ \mathrm{SDM} & =\text { Human Resources } \\ \mathrm{KP} & =\text { Corruption } \\ \mathrm{t} & =1,2 \ldots \mathrm{T} \text { (Times) } \\ \mu & =\text { Error term }\end{array}$

\section{RESULT AND DISCUSSION \\ Decentralized degree ratio}

The degree of decentralization is the ability of regional governments to increase regional original income to finance development with fiscal decentralization, the local government is expected to be able to manage and manage the available resources as well as possible independently to improve the welfare of the community. The degree of decentralization is calculated based on a comparison between the amount of PAD and the Total Regional Revenue.

Table-4: Fiscal decentralization ratio in Jambi Province 2000-2017

\begin{tabular}{|c|c|c|c|c|c|c|}
\hline Year & PAD & $\%$ & TPD & $\%$ & PAD/TPD & DDF \\
\hline 2000 & 69.851 .417 .357 & 68,66 & 174.360 .850 .866 & 83,94 & 40,06 & Well \\
\hline 2001 & 82.232 .143 .000 & 17,72 & 297.734 .347 .000 & 70,76 & 27,62 & Medium \\
\hline 2002 & 111.000 .834 .369 & 34,98 & 449.304 .175 .000 & 50,91 & 24,71 & Medium \\
\hline 2003 & 187.639 .300 .115 & 69,04 & 616.193 .475 .000 & 37,14 & 30,45 & Enough \\
\hline 2004 & 246.236 .225 .000 & 31,23 & 630.144 .010 .000 & 2,26 & 39,08 & Enough \\
\hline 2005 & 347.837 .812 .858 & 41,26 & 748.820 .793 .000 & 18,83 & 46,45 & Well \\
\hline 2006 & 385.042 .833 .000 & 10,70 & 819.586 .370 .000 & 9,45 & 46,98 & Well \\
\hline 2007 & 382.082 .234 .000 & $-0,77$ & 1.010 .116 .940 .000 & 23,25 & 37,83 & Enough \\
\hline 2008 & 454.4 & 18,94 & 1.155 .350 .580 .000 & 14,38 & 39,33 & Enough \\
\hline 2009 & 526.442. & 15,84 & 1.436 .448$. & 24,33 & 36,65 & Enough \\
\hline 2010 & 686.629 .362 .314 & 30,43 & 1.353 .900 .460 .000 & $-5,75$ & 50,71 & Very Wel \\
\hline 2011 & 984.232 .579 .912 & 43,34 & 1.640 .185 .860 .000 & 21,15 & 60,01 & Very Wel \\
\hline 2012 & 713.559 .311 .667 & $-27,50$ & 1.734 .302 .270 .000 & 5,74 & 41,14 & Well \\
\hline 2013 & 804.414 .207 .083 & 12,73 & 2.446 .374 .630 .000 & 41,06 & 32,88 & Enough \\
\hline 2014 & 973.070 .077 .063 & 20,97 & 2.981 .991 .350 .000 & 21,89 & 32,63 & Enough \\
\hline 2015 & 1.218 .125 .069 .042 & 25,18 & 3.293 .250 .800 .000 & 10,44 & 36,99 & Enough \\
\hline 2016 & 273.892 .96 & 4,58 & 3.394 .795 .87 & 3,08 & 37,52 & Enough \\
\hline 2017 & 1.393 .072 .790 .798 & 9,36 & 4.163 .724 .816 .402 & 22,65 & 33,46 & Enough \\
\hline & Average & \multicolumn{2}{|c|}{24,75} & 28,12 & 39,63 & Enough \\
\hline
\end{tabular}

Source: Regional financial and asset management agency in Jambi Province

Based on Table 4 it can be seen that from 2000-2017 the percentage of Regional Original Revenue or PAD to Total Regional Revenue or TPD has fluctuated. The magnitude of the contribution of PAD to Total Regional Revenues from 2000-2017 which experienced fluctuations during this period illustrates the degree of unstable fiscal decentralization. In 2004, the contribution of PAD to TPD was 39.08 percent. The percentage increase in TPD occurs in an increase and decrease that is not stable each year. This is due to an increase in PAD and balanced funds. But in 2008 there was a decrease of 39.33 percent due to a decrease in Regional Original Revenue or PAD. The average total regional revenue during 1998-2017 was 28.12 percent. While the average contribution of PAD to TPD was 39.63 percent.The development of the degree of fiscal decentralization in Jambi Province in 2002-2006, the percentage of PAD to TPD experienced a significant increase. But in 2007 the percentage of PAD to TPD again declined by 37.83 percent. The best percentage of PAD to TPD during the last seventeen years occurred in 2012 at 60.01 percent. Based on Figure 1, the average degree of decentralization ratio in the Jambi Provincial Government in 2000-2017 with an average of 39.63 percent. 


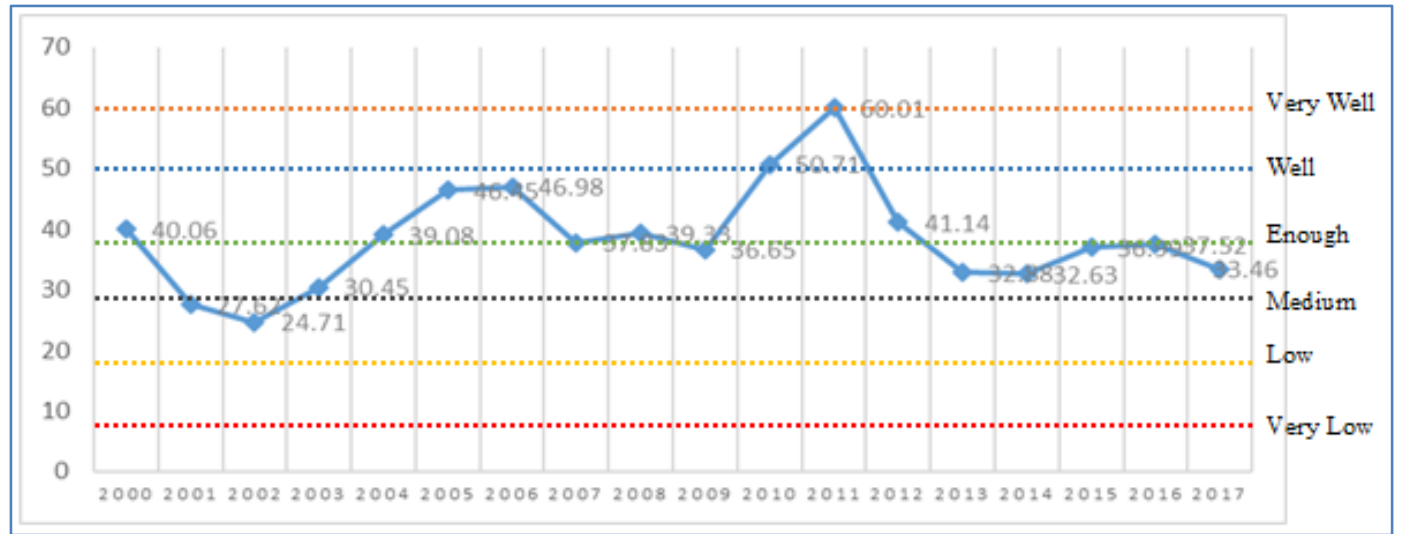

Fig-1: Development of the degree of decentralization of Jambi Province in 2000-2017 Source: Data processed, 2018

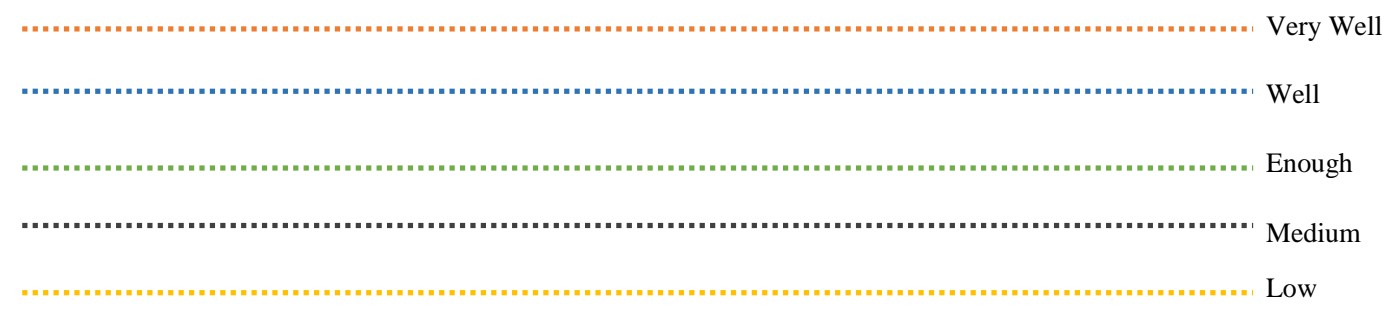

Very Low

Furthermore, it can be said that the financial performance of the Jambi provincial government seen from the comparison of PAD to Total Regional Revenue is quite good, but not optimal. It is necessary to improve performance through strategic steps to increase PAD by exploring existing potential through intensification and the extensification of regional revenue.

\section{Ratio of regional financial independence}

Based on the ratio of the level of financial independence it is known that in the period of the fiscal year 2000 - 2017 shows a percentage that fluctuates each year. Level of Regional Financial Independence in Jambi Province in 2012 the Regional Independence Ratio with a percentage of 42.84 percent categorized as low ability.

Table-5: Development of regional financial independence ratio of Jambi Province in 2000-2017

\begin{tabular}{|r|r|r|c|c|}
\hline Year & PAD & DTF & PAD/DTF & KKD \\
\hline 2000 & 69.851 .417 .357 & 104.398 .370 .871 & 66,91 & Medium \\
\hline 2001 & 82.232 .143 .000 & 131.738 .152 .072 & 62,42 & Medium \\
\hline 2002 & 111.000 .834 .369 & 237.453 .112 .000 & 46,75 & Low \\
\hline 2003 & 187.639 .300 .115 & 266.403 .018 .000 & 70,43 & Medium \\
\hline 2004 & 246.236 .225 .000 & 279.894 .258 .000 & 87,97 & High \\
\hline 2005 & 347.837 .812 .858 & 393.688 .551 .000 & 88,35 & High \\
\hline 2006 & 385.042 .833 .000 & 532.035 .039 .025 & 72,37 & Medium \\
\hline 2007 & 382.082 .234 .000 & 704.299 .703 .877 & 54,25 & Medium \\
\hline 2008 & 454.441 .987 .000 & 805.271 .241 .378 & 56,43 & Medium \\
\hline 2009 & 526.442 .077 .650 & 826.020 .480 .233 & 63,73 & Medium \\
\hline 2010 & 686.629 .362 .314 & 953.131 .620 .365 & 72,04 & Medium \\
\hline 2011 & 984.232 .579 .912 & 1.093 .207 .719 .995 & 90,03 & High \\
\hline 2012 & 713.559 .311 .667 & 1.665 .586 .782 .809 & 42,84 & Low \\
\hline 2013 & 804.414 .207 .083 & 1.854 .055 .309 .316 & 43,39 & Low \\
\hline 2014 & 973.070 .077 .063 & 1.882 .125 .324 .008 & 51,70 & Medium \\
\hline 2015 & 1.218 .125 .069 .042 & 1.899 .918 .484 .381 & 64,11 & Medium \\
\hline 2016 & 1.273 .892 .966 .618 & 2.045 .036 .815 .556 & 62,29 & Medium \\
\hline 2017 & 1.393 .072 .790 .798 & 2.766 .192 .134 .604 & 50,36 & Medium \\
\hline & Average & & $\mathbf{6 3 , 5 7}$ & Medium \\
\hline
\end{tabular}

Source: Regional Finance Agency in Jambi Province (processed) 
Based on Table 5 shows that in 2013 the Regional Independence Ratio decreased again due to Regional Original Revenue funds and transfer funds have a percentage of 43.39 percent which is categorized as low capability, but in 2014 the Regional Independence Ratio increased again with a large percentage of 64.11 percent due to central transfer funds up from the previous year. The average percentage of the Regional Independence Ratio in the Province of Jambi during 1998-2017 was 63.57 percent and in the medium ability category.

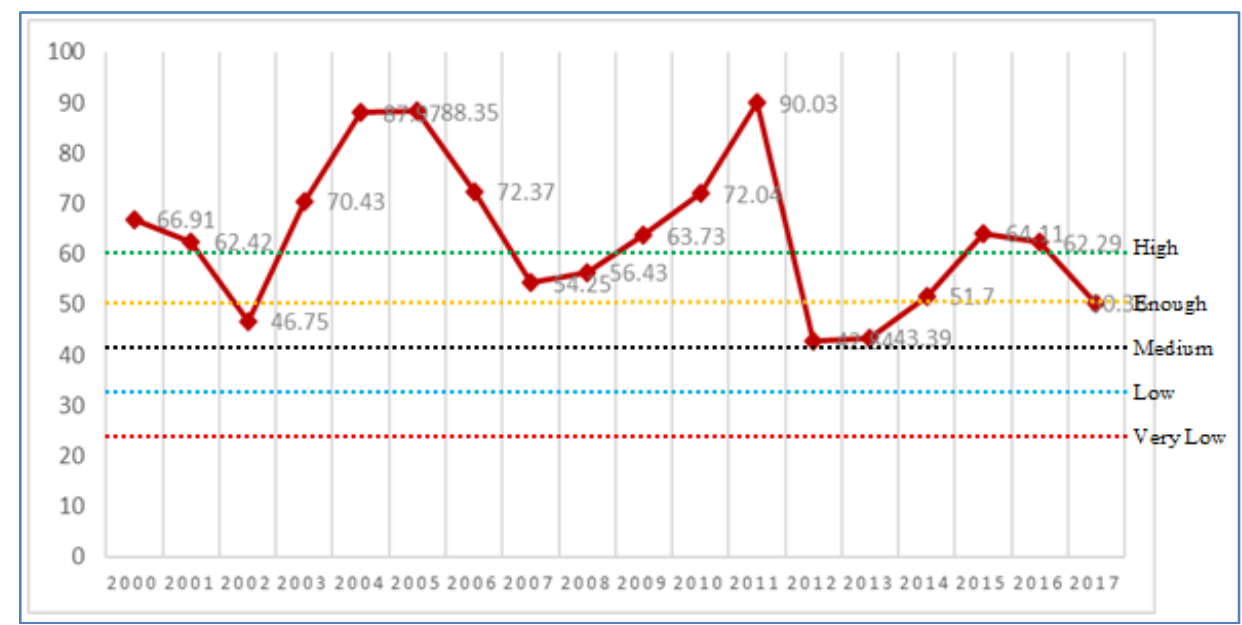

Fig-2: Development of Regional Independence Level Based on Transfer Income Ratio to TPD Jambi Province 2000-2017 Source: Regional Finance Agency in Jambi Province, 2000-2017 (processed)

Implementation of regional autonomy policies through optimization of the acquisition of regional income sources. The fact is that regional independence will depend very much on the large potential of local revenue sources to finance regional expenditure. Based on the ratio of the level of financial independence of the provincial government of Jambi during the period of the 2000-2017 fiscal years, the average level of independence was 63.57 percent. It is classified according to the criteria for evaluating the financial independence of the region is a province with a medium level of financial independence. So that shows that the province of Jambi during the period 2000-2017 has moderate financial independence so that it has a fairly high dependence on funds transfer assistance from the center in implementing regional autonomy and fiscal decentralization.

\section{Micro regression analysis}

This study consists of three independent variables namely politics, corruption, human resources. While the dependent variable in this study is the budget performance of government agencies or OPD in Jambi Province. To estimate the variables in this study used Ordinary Least Square (OLS), an econometric model. The estimation results of the research model are as follows:

Table-7: Ordinary Least Square (OLS) model estimation results

\begin{tabular}{|c|c|c|c|c|c|c|c|c|}
\hline \multicolumn{2}{|c|}{ Model } & \multicolumn{2}{|c|}{ Unstandardized Coefficients } & \multirow{2}{*}{$\begin{array}{c}\begin{array}{c}\text { Standardized } \\
\text { Coefficients }\end{array} \\
\text { Beta }\end{array}$} & \multirow[t]{2}{*}{$\mathbf{t}$} & \multirow[t]{2}{*}{ Sig. } & \multicolumn{2}{|c|}{ Collinearity Statistics } \\
\hline & & B & Std. Error & & & & Tolerance & VIF \\
\hline \multirow[t]{4}{*}{1} & (Constant) & -53.141 & 10.244 & & -5.187 & .000 & & \\
\hline & Political & -.602 & .153 & -.316 & -3.925 & .000 & .894 & 1.119 \\
\hline & Corruption & -.598 & .282 & -.197 & -2.122 & .038 & .672 & 1.488 \\
\hline & $\begin{array}{l}\text { Human } \\
\text { Resources }\end{array}$ & 1.408 & .237 & .547 & 5.951 & .000 & .686 & 1.458 \\
\hline
\end{tabular}

Source: Data processed, 2019 
Based on Table 7 it is known that the significance values of the three independent variables in politics, corruption, and human resources are 0,000 , 0.038 and 0.0000 less than the significance level $\alpha=$ 0.05 . These results provide the conclusion that each party increase or increase in political interests, the
Jambi Province OPD budget performance will decrease and each increase in corruption, the budget performance will also decrease. Meanwhile, any improvement in the quality of human resources will improve the performance of the OPD budget in Jambi Province.

\section{Classic assumption test \\ Normality test}

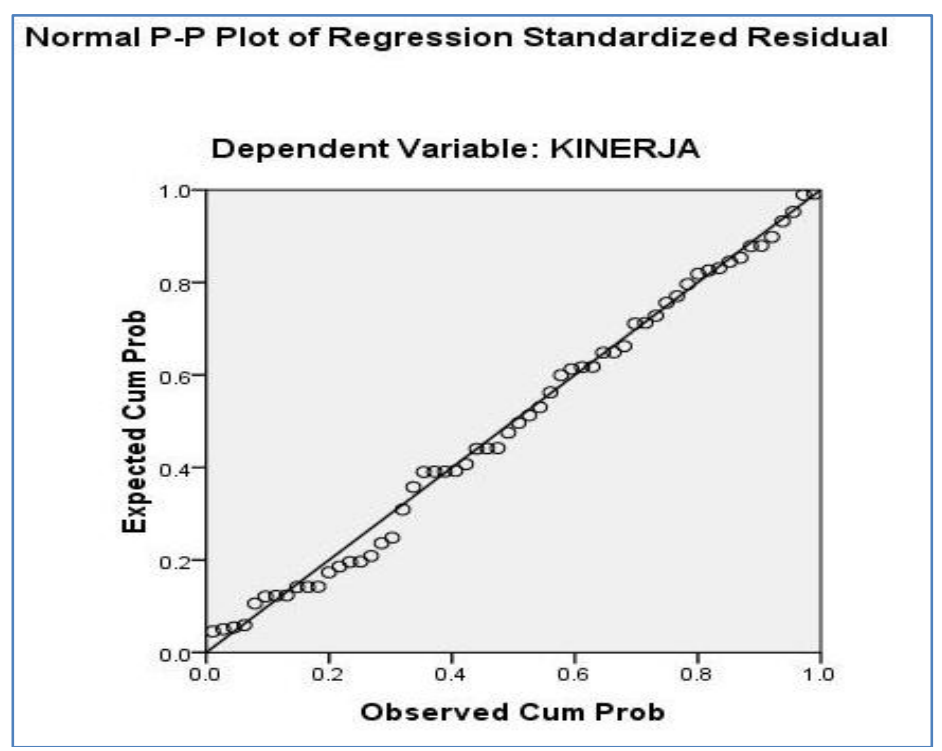

Fig-3: Normality test

Source: Data processed, 2019

The normality test aims to test whether in the regression model, the dependent variable and the independent variables both have normal distributions or not. The normality test is done by looking at the pattern on the Plot P distribution curve. The following are the results of normality tests on the independent and dependent variables.

Based on Figure 3 it is known that the points in the normal image Probability tend to form diagonal lines, so it can be concluded that the dependent variable and the independent variable both have a normal distribution.

\section{Multicollinearity test}

This test is useful to find out whether the proposed regression model has found a correlation between independent variables. A good model should not occur the correlation between independent variables. To detect the presence of multicollinearity can be done by finding the amount of variance inflation factor (VIF) and the tolerance value. If the VIF value is less than 10 and the tolerance value is more than 0.1 then the regression is free from multicollinearity.

Table-8: Multicollinearity Test

\begin{tabular}{|c|c|c|c|c|c|c|c|c|}
\hline \multirow{2}{*}{\multicolumn{2}{|c|}{ Model }} & \multicolumn{2}{|c|}{$\begin{array}{c}\text { Unstandardized } \\
\text { Coefficients }\end{array}$} & \multirow{2}{*}{$\begin{array}{c}\begin{array}{l}\text { Standardized } \\
\text { Coefficients }\end{array} \\
\text { Beta }\end{array}$} & \multirow[t]{2}{*}{$\mathbf{t}$} & \multirow[t]{2}{*}{ Sig. } & \multicolumn{2}{|c|}{$\begin{array}{l}\text { Collinearity } \\
\text { Statistics }\end{array}$} \\
\hline & & B & Std. Error & & & & Tolerance & VIF \\
\hline \multirow[t]{4}{*}{1} & (Constant) & -53.141 & 10.244 & & -5.187 & .000 & & \\
\hline & Political & -.602 & .153 & -.316 & -3.925 & .000 & 0.894 & 1.119 \\
\hline & Corruption & -.598 & .282 & -.197 & -2.122 & .038 & 0.672 & 1.488 \\
\hline & Human Resources & 1.408 & .237 & .547 & 5.951 & .000 & 0.686 & 1.458 \\
\hline
\end{tabular}

Source: Data processed, 2019

Based on Table 8 it is known that the tolerance value for the three variables is less than 1 and the magnitude of VIF is not more than 10 so it can be concluded that there is no multicollinearity between the independent variables.

\section{Heteroscedasticity test}

Heteroscedasticity test is carried out to find out whether in a regression there is an inequality of variance from residuals of one observation to another. If the variance from residual observations to other observations is different, it means there are symptoms 
of heteroscedasticity. Testing of heteroscedasticity can be done by observing the presence or absence of certain patterns in the scatter plot graph generated through SPSS.

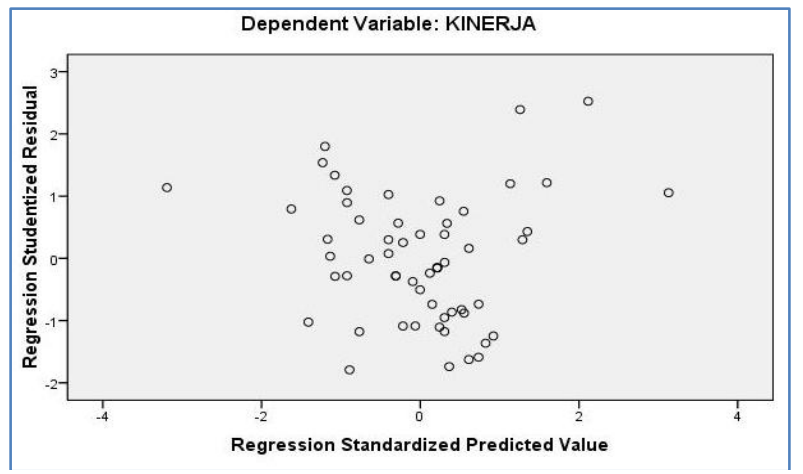

Fig-4: Scatter Plot

Source: Data processed, 2019
Based on the scatterplot figure 4 it is known that the points on the image spread randomly below and above the zero and do not form a special pattern. It can be concluded that in this study heteroscedasticity did not occur.

\section{Simultaneous significance test (F test)}

To find out the influence of politics, corruption and human resources on the performance of the budget simultaneously performed $\mathrm{F}$ test using SPSS 22. Indicators of the significance of the coefficient parameters are significant or not, it can be tested with the help of the Fisher method statistical test (F test) with a confidence level of $95 \%$. The test criteria used are if F-count> F-table, then Ho is rejected; and if F-count $<$ F-table, Ho can be accepted.

Table-9: Simultaneous tests

\begin{tabular}{|l|l|r|r|r|r|c|}
\hline \multicolumn{2}{|l|}{ Model } & Sum of Squares & \multicolumn{1}{c|}{ df } & Mean Square & \multicolumn{1}{c|}{ F } & \multicolumn{1}{c|}{ Sig. } \\
\hline 1 & Regression & 2438.79 & 3 & 812.93 & 39.52 & $.000^{\mathrm{a}}$ \\
\hline & Residual & 1110.797 & 54 & 20.57 & & \\
\hline & Total & 3549.586 & 57 & & & \\
\hline
\end{tabular}

Source: Data processed, 2019

Base on the Table 9 the calculated F-value is 39.52 while the F-table at the $95 \%$ confidence level $(\alpha=$ $0.05)$ is 2.47 . This means that the value of F-count> Ftable $(39.52>2.47)$. This gives the meaning that the political variables, corruption, and human resources together (simultaneously) significantly influence the performance of the OPD budget in Jambi Province. Thus the hypothesis stating that political variables, corruption, and human resources influence the budget performance of the OPD in Jambi Province is accepted.

\section{Coefficient of determination}

The hypothesis in this study is politics, corruption, and human resources affect the performance of the budget in Jambi Province OPD. Conformity test is conducted to determine the feasibility of a regression model because the research variables are more than two variables, it can be seen from the value of $\mathrm{R}$ squared.To find out the magnitude of political contributions, corruption, and human resources to budget performance simultaneously can be known based on the value of $R$ Square in the Summary model Table 10.

Tabel-10: Coefficient of determination $\left(\mathbf{R}^{2}\right)$

\begin{tabular}{|r|c|r|r|r|r|}
\hline Model & R & R Square & Adjusted R Square & Std. Error of the Estimate & Durbin-Watson \\
\hline $\mathbf{1}$ & $.829^{\mathrm{a}}$ & 0.687 & 0.67 & 4.53545 & 2.035 \\
\hline A. Predictors: (Constant), Human Resources, Politics, Corruption \\
\hline
\end{tabular}

Source: Data processed, 2019

Based on Table 10 shows that the $\mathrm{R}$ squared value of 0.687 , shows that 68.70 percent of the budget performance variable can be explained by the independent variables namely political variables, corruption, and human resources. The remaining less than 31.3 percent is influenced by other variables not explained by this research model.

\section{Partial significance test (t-test)}

To find out whether or not there is an influence between the independent variables on the dependent variable partially can be done using the t-test base on table 7 . This study shows that politics has a negative but significant influence on the performance of the OPD budget in Jambi Province.

\section{Political influence on the OPD budget performance of Jambi Province}

From the results of the t-test conducted in Table 7 , the resulting value for the corruption variable is 3,925 (refer to the t-test results table). This value is greater than the t-table value of 1.66177 . With the value of the t-count> t-table, the political variables significantly influence the budget performance. This is 
reinforced by the resulting probability value of 0.0000 is small from the probability value $\alpha=0.05$. Thus, politics significantly influence the performance of the OPD budget in Jambi Province. Based on the test results also obtained the value of the political regression coefficient of minus 0.602 (refer to Table 7), which means that each increase in political interests by 1 unit, will reduce the performance of the OPD budget in Jambi Province by 0.602 units. The results of this study are consistent with the initial hypothesis which states that politics has a significant effect on the performance of the OPD budget in Jambi Province.

The results of this study prove that in the process of budgeting, budget politics and human resource capacity have a huge influence so that the budgeting process can run effectively, efficiently to increase government accountability. Given the budget preparation process is very important in government.

This is consistent with the research [40] which shows that the budgeting process in Indonesia is inseparable from politics, where the role of parliament is very large in this process, this is seen in the stage of budget approval negotiations. Furthemore research by Kurniasih [41] which shows that the capacity of human resources is one of the factors that are indispensable in the budget preparation process. The results showed that budget politics had a significant effect on the process of budgeting. This can be seen in the value of t-statistics> t-table. This means that the level of the budget preparation process is influenced by budget politics, where if the budget politics are good then the budgeting process can run well too. The results of this study are consistent with previous studies conducted by Moraes, Chasquetti, and Bergara [42], Mangambi and Tauri [43] which show that budget politics influence the budgeting process.

\section{CONCLUSION AND RECOMMENDATION Conclusion}

This study shows that politics has a negative but significant influence on the performance of the OPD budget in Jambi Province. This study shows that corruption has a negative but significant effect on the performance of the OPD budget in Jambi Province. Based on the test results also obtained the value of the corruption regression coefficient of minus 0.598 (refer to Table 5.9), which means that each increase of corruption by 1 unit, will reduce the OPD budget performance in Jambi Province by 0.598 units.

The human resource variable has a positive and significant effect on the performance of the OPD budget in Jambi Province. From the results of the t-test performed, the value generated for the human resource variable is 5.47 (refer to the t-test results table).

\section{RECOMMENDATION}

Ways to cut public budgets in the political process by the political elite are a betrayal of the people. Then the people's participation has been represented through the House of Representatives and the political/executive elite. Budgeting process, budget politics, and human resource capacity have a very big influence so that the budgeting process can run effectively, efficiently so that it can increase government accountability. Given the budget preparation process is very important in government. Moreover transparency, accountability becomes a fixed price in the budget political process. In general, budget politics is considered a domain of the government so that even in the era of democracy, public participation is considered a threat by the central and regional governments.

Budget engineering has become a daily food in managing public budget management both central and local governments. This optimism arises when the development of a democratic political system in determining public budget allocations.

\section{REFERENCES}

1. Bratakusumah, D. S. (2001). Otonomi penyelenggaraaan pemerintahan daerah: Deddy Supriady Bratakusumah, Dadang Solihin. Gramedia Pustaka Utama.

2. Sriyana, J. (2007). Pengembangan model dinamik Error Correction Model (ECM) untuk analisis ketahanan fiskal di Indonesia: Research report, Faculty of Economics, Economics Department, Universitas Islam Indonesia.

3. Maryatmo, R. (2004). Dampak Moneter Kebijakan Defisit Anggaran Pemerintah dan Peranan Asa Nalar Dalam Simulasi Model Makro-Ekonomi Indonesia (1983: 1-2002: 4). Buletin Ekonomi Moneter dan Perbankan, 7(2), 297-322.

4. Waluyo, J. (2009). Peranan Pajak untuk Meningkatkan Kemandirian Anggaran.

5. Nizar, M. A. (2013). Pengaruh Defisit Anggaran Terhadap Defisit Transaksi Berjalan Di Indonesia.

6. Labibah, S. (2017). Analisis Hubungan Defisit Anggaran Dan Inflasi Di Indonesia. Etd Unsyiah.

7. Khairunnisa, A., \& Farlian, T. (2018). Analisis pengaruh variabel makro dan defisit anggaran di indonesia. Jurnal Ilmiah Mahasiswa Ekonomi Pembangunan, 3(4), 625-632.

8. Nurfadhilah, N., \& Silvia, V. (2017). Pengaruh utang pemerintah terhadap suku bunga di indonesia. Jurnal Ilmiah Mahasiswa Ekonomi Pembangunan, 2(3), 404-413.

9. Ardyanto, D. (2002). Korupsi, Demokrasi dan Kapitalisme: sebuah Manifesto Bagi Gerakan Sosial Anti Korupsi. Indonesian Journal of Criminology, 2(1), 4216.

10. Sihombing, P. W., \& Widhiyanto, I. (2008). Modul Perencanaan Kas: Third edition. Jakarta: 
Direktorat Pengelolaan Kas Negara, Direktorat Jenderal Perbendaharaan.

11. Putri, A. A. M. R. A. (2014). Pengaruh Gaya Kepemimpinan, Budaya Organisasi dan Kompensasi Finansial terhadap Kepuasan Kerja Karyawan pada PT. Dunia Garmen Internasional di Denpasar. E-Jurnal Manajemen, 3(1).

12. Utomo, K. W. (2002). Kepemimpinan dan pengaruhnya terhadap perilaku citizenship (OCB), kepuasan kerja dan perilaku organisasional (penelitian empiris pada kabupaten kebumen). Jurnal Riset Ekonomi dan Manajemen, 2(2), 34-52.

13. Halim, A. (2001). Bunga Rampai Manajemen Keuangan Daerah. UPP AMP YKPN: Yogyakarta

14. Halim, A. (2001). Analisis Deskriptif Pengaruh Fiscal stress Pada APBD Pemerintah Daerah Kabupaten/Kota di Jawa Tengah. Yogyakarta: STIE.

15. Yani, A.(2002). Hubungan Keuangan antara Pemerintah Pusat dan Daerah di Indonesia. PT Raja Grafindo Persada: Jakarta

16. Widjaja, H.(2007). Titik Berat Otonomi Pada Daerah tingkat II. X PT. Bumi Askara: Jakarta

17. Mardiasmo. (2009). Akutansi Sektor Publik. Andi: Yogyakarta

18. Bastian, I.(2010). Akuntansi Sektor Publik Third edition. Erlangga: Jakarta

19. Wahyuningtyas, A. E., \& Arianti, F. (2010). Analisis pengaruh pengeluaran pemerintah dan defisit anggaran terhadap investasi di indonesia tahun 1986-2008 (Doctoral dissertation, universitas diponegoro).

20. Halim,A. (2014). Manajemen Keuangan Sektor Publik problematika penerimaan dan pengeluaran pemerintah. Selemba Empat: Jakarta

21. Riwayadi. (2014). Akutansi Biaya:Pendekatan Tradisional dan Kontemporer. Salemba Empat: Jakarta

22. Sedarmayanti.(2003). Good Governance Dalam Rangka Otomi daerah, Maju Mundur: Bandung

23. Mardiasmo.(2002). Perpajakan. Revision edition 2009. Andi: Yogyakarta

24. Ahyani, W. (2010). Analisis Pengaruh Pendapatan Asli Daerah Dan Belanja Daerah Terhadap Pertumbuhan Ekonomi Daerah, dan Pengganguran Pasca Pelaksanaan Otonomi Daerah (Studi Kasus Pada Kabupaten Dan Kota Provinsi Jawa Tengah). Undergraduate thesis. Universitas Brawijaya: Malang

25. Laksana, F. (2008). Manajemen Pemasaran. Graha Ilmu: Yogyakarta
26. Boediono.(2001). Ekonomi Makro, Seri Sinopsis Pengantar Ilmu Ekonomi No. 2. 21st edition. BPFE:Yogyakarta.

27. Barro, R. J.(1989). The Ricardian Approach to Budget Deficits. Journal of Economic Perspectives, 3(2), 37-54

28. Erlina, R. (2013). Akuntansi Keuangan Daerah Berbasis Akrual, Brama Ardian: Medan

29. Bland, R. L., \& Nunn, S. (1992). The impact of capital spending on municipal operating budgets. Public Budgeting \& Finance, 12(2), 3247.

30. Kuznets Simon, E. G. (1964). the Contribution of Agriculture.

31. Todaro, M. P. (2000). Pembangunan Ekonomi di Dunia Ketiga Seventh edition. Jakarta: erlangga.

32. Tan, S. (2012). Perencanan Ekonomi dan Implikasinya Dalam Pembangunan Daerah. Faculty of Economics and Business. Universitas Jambi: Jambi.

33. Ardito, B.(2003).Disparitas Pertumbuhan Ekonomi Jawa dan Luar Jawa, Jurnal Ekonomi Pembangunan, 8(1), 39-48

34. Dornbush, R., Fisher, S., \& Startz, R. (2004). Makroekonomi, Jakarta: PT. Media Global Edukasi.

35. Sugiyono. (2012). Metode Penelitian Kuantitatif Kualitatif dan $R \& D$. Alfabeta: Bandung

36. Husein, U. (2005). Studi Kelayakan Bisnis. Edisi Ketiga. Jakarta: PT. Gramedia Pustaka Utama.

37. Suharsimi, A. (2006). Prosedur penelitian suatu pendekatan praktik. Jakarta: Rineka Cipta.

38. Gujarati, D. (2004). Ekonometrika Dasar.( Translated by Sumarno Zain). Erlangga: Jakarta.

39. Blondal, J.(2003). Accrual Accounting and Budgeting: Key Issues and Recent Developments. OECD Journal on Budgeting, 3(1), 43-131

40. Kurniasih, W. (2007). Analisis Proses Penyusunan Dan Penetapan Anggaran Dinas Kesehatan Yang Bersumber dari APBD Kota Tasikmalaya, Master's Thesis. Universitas Diponegoro: Semarang

41. Moraes, J. A., Chasquetti, D., \& Bergara, M. (2006). The Political Economy of the Budgetary Process in Uruguay. InterAmerican Development Bank. Research Dept. III. Latin American Research Network. IV. Series. Instituto de Ciencia Política, Universidad de la República Oriental del Uruguay.Instituto de Ciencia Política, Universidad de la República Oriental del Uruguay, 320(1), 1-66

42. Mugambi, K. W., \& Fridah, S. T. (2014). The Challenges Encountered By Country Goverment In Kenya During Budget Prepartion. IOSR, Journal of Bisiness and Management, 16(2), 128-134. 